\title{
Effectiveness of cyanoacrylate adhesive in rabbit aortorrhaphy
}

\author{
Efetividade do adesivo de cianoacrilato para aortarrafia em coelhos
}

Marcus Vinicius Henriques de Carvalho', Evaldo Marchi', Mario Pantaroto'

\begin{abstract}
Background: Even when properly performed, arterial sutures are not always absolutely hemostatic. Tissue sealants and adhesives have become available that can be used to complete sutures, preventing hemorrhage problems. Objectives: To evaluate the effectiveness of cyanoacrylate adhesive for sealing aortotomies in rabbits in a coagulopathic state, by analyzing survival of the animals and the time taken to achieve hemostasis. Methods: Ten-mm long aortotomies were performed on the infrarenal aortas of 12 animals. In four animals, aortorrhaphy was conducted using four interrupted polypropylene sutures and in the remaining animals aortorrhaphy was performed using four or fewer polypropylene stitches, followed by application of a cyanoacrylate adhesive. Results: The four animals sutured without adhesive died within the postoperative period due to severe hemorrhage ( 3 animals) or intestinal ischemia. The eight animals to which the adhesive was applied exhibited no transoperative bleeding, but one animal died during the postoperative period. Using cyanoacrylate permitted more rapid procedures $(p<0.004)$ and no local reactions were observed in macroscopic examination of tissues. Conclusions: The cyanoacrylate adhesive demonstrated effectiveness for sealing aortotomies, considering the survival outcomes, duration of procedures and absence of local reactions on macroscopic examination.
\end{abstract}

Keywords: tissue adhesives; aorta; surgery; animal experimentation.

\begin{abstract}
Resumo
Contexto: Ainda quando feitas adequadamente, suturas arteriais não são absolutamente hemostáticas. Vedantes e adesivos teciduais estão disponíveis e podem ser usados para completar as suturas, prevenindo problemas hemorrágicos. Objetivos: Avaliar a efetividade do adesivo de cianoacrilato em vedar aortotomias de coelhos, considerando a sobrevida dos animais e o tempo para hemostasia. Métodos: Em todos os doze animais, aortotomias de $10 \mathrm{~mm}$ de extensão foram feitas na aorta abdominal infrarrenal. Em quatro animais a aortorrafia foi feita com quatro pontos separados de polipropileno, e no outro grupo, a aortorrafia foi feita com quatro ou menos pontos separados e, depois, o adesivo de cianoacrilato foi aplicado. Resultados: Os quatro animais que receberam somente a sutura morreram no primeiro dia de pós-operatório devido à hemorragia intensa (três animais) e por isquemia intestinal. Nos oito animais nos quais o adesivo foi aplicado não houve sangramento transoperatório, mas um animal morreu no período pós-operatório. A utilização do cianoacrilato tornou o procedimento mais rápido $(p<0,004)$. Não foram observadas reações locais sob o ponto de vista macroscópico. Conclusões: $\mathrm{O}$ adesivo de cianoacrilato mostrou efetividade em vedar aortotomias, considerando o desfecho sobrevida e tempo para obter hemostasia e o fato de não ocorrerem reações locais sob o ponto de vista macroscópico.
\end{abstract}

Palavras-chave: adesivos teciduais; aorta; cirurgia; experimentação animal. 


\section{INTRODUCTION}

Routine arterial closure using surgical sutures is effective in the great majority of cases and patients have benefited from the technique for many years. However, arterial suture is time-consuming, which is sometimes undesirable in cases such as carotid, abdominal aorta and coronary graft sutures. Even when properly performed, arterial sutures may fail to achieve absolute hemostasis, most frequently in patients on antiplatelet drugs or in patients with coagulopathies who require surgery despite the presence of these conditions. Surgical sealants and adhesives have recently become available and can be used to supplement sutures, preventing hemorrhagic problems. There are two main types of surgical adhesive: biological adhesives based on fibrin and chemical adhesives based on cyanoacrylate. Adhesives based on cyanoacrylate began to be used in 1960, but at that time there were concerns that cyanoacrylate could lead to strong tissue reactions. However, in modern formulations the product is safe and causes almost imperceptible reactions. ${ }^{1,2}$ Nevertheless, there is a need for further research into the effectiveness of cyanoacrylate in vascular sutures.

This research was conducted to investigate the effectiveness of cyanoacrylate adhesive in an experimental model of aortorrhaphies in rabbits, evaluating postoperative complications (hemorrhage, thrombus, death, gross macroscopic changes, and local reactions) and the time required to perform aortorrhaphy using the gluing method. The coagulopathic state was induced by administration of heparin, without reversal using protamine.

\section{MATERIAL AND METHODS}

The study was conducted on 12 rabbits with an average weight of 4,070 $\mathrm{kg}$ (3,500 to 4,450 kg), handled in accordance with rules published by Brazil's National Council for the Control of Animal Experimentation. ${ }^{3}$ The study was also approved by the Research Ethics Committee at the Institution. Animals were kept in individual cages and cared for in the FMJ vivarium. On the day of the procedure, each animal was brought to the FMJ Surgical Technique Laboratory and anesthetized with acepromazine (Acepran ${ }^{\circledR}$, Univet, S. Paulo) and tiletamine+zolazepam $\left(\right.$ Zoletil $^{\circledR}$, Virbac, S. Paulo). After anesthesia, venous access was obtained and the abdominal region was shaved and submitted to antisepsis and asepsis, followed by placement of sterile surgical fields. All operations were performed by the same surgeon with constant asepsis. Frontal light and a surgical loupe with $2.5 \mathrm{x}$ magnification were used in all operations, to facilitate careful arteriorrhaphy, avoiding stenosis of the vessel.

An intraperitoneal approach to the infrarenal abdominal aorta was obtained by anterior median laparotomy and a segment of the vessel approximately $30 \mathrm{~mm}$ long was exposed. At this stage, heparin $(100 \mathrm{mg} / \mathrm{kg})$ (Hepamax-S ${ }^{\circledR}$, Blausiegel, S. Paulo) was administered intravenously and after 2 minutes an infrarenal aorta segment was occluded with gentle compression by two vascular clamps (Codman Instruments ${ }^{\circledR}$, USA) to prevent bleeding. The heparin dose was not reversed with protamine in order to create a state of coagulopathy. A 10-mm incision was made in the anterior part of this aortic segment using an ophthalmic scalpel. Up to this point, all animals were submitted to the same procedures. They were then assigned to one of two groups, as defined in Table 1. Briefly, in the suture group aortorrhaphy was performed using four interrupted sutures and in the suture + adhesive group aortorrhaphy was accomplished using interrupted sutures + adhesive. The reason for choosing interrupted sutures instead of continuous sutures was to make it possible to determine how large the distance between stitches could be and still be sealed by the adhesive. To determine this limit, the authors reduced the numbers of stitches by one stitch per case successively, because the adhesive applied after aortorrhaphy exhibited high sealing power and reliability. As a result, animal No. 5 (the first in the sutures + adhesive group) received four stitches, animal No. 6, three stitches, animal No. 7, two stitches and animals 8 through 12 were treated with just one stitch each. After removing the vascular clamps from the aorta and checking for bleeding, intestinal loops were re-conducted to their original positions over the aorta, the abdominal wall was sutured, and the animals were returned to the vivarium. The sequence of procedures is illustrated in Figure 1. Postoperative analgesia was provided by adding dipyrone to the animals' water dispensers.

The tissue adhesive used was Omnex ${ }^{\circledR}$ (Ethicon, Johnson \& Johnson, S. José dos Campos, SP, Brazil). The product was applied sparingly, using a partial drop to create a thin film over the suture line.

\section{Statistical analysis}

Fisher's exact test was used to determine whether there were differences in the primary outcome (animal death) when those animals treated with sutures only and those treated with suture + adhesive were compared. Student's $t$ test was used to assess differences between the time taken to perform aortorrhaphy in the two groups. Results with $p<0.05$ were considered significant. 
Table 1. Procedures and animal outcome.

\begin{tabular}{clll}
\hline Animal No. & \multicolumn{1}{c}{ Procedure } & \multicolumn{1}{c}{ Outcome } & Cause of death/macroscopic tissue examination \\
\hline 1 & 4 stitches & Death $<24 \mathrm{hr}$ & Hemorrhagic shock \\
2 & 4 stitches & Death $<24 \mathrm{hr}$ & Hemorrhagic shock \\
3 & 4 stitches & Death $<36 \mathrm{hr}$ & Hemorrhagic shock \\
4 & 4 stitches & Death in $72 \mathrm{hr}$ & Intestinal ischemia \\
5 & 4 stitches + adhesive & Survival until euthanasia day & Recent parietal thrombus \\
6 & 3 stitches + adhesive & Survival until euthanasia day & Organized parietal thrombus \\
7 & 2 stitches + adhesive & Death within $72 \mathrm{hr}$ & Sepsis \\
8 & 1 stitch + adhesive & Survival until euthanasia day & Organized parietal thrombus \\
9 & 1 stitch + adhesive & Survival until euthanasia day & Recent parietal thrombus \\
10 & 1 stitch + adhesive & Survival until euthanasia day & Organized parietal thrombus \\
11 & 1 stitch + adhesive & Survival until euthanasia day & Recent parietal thrombus \\
12 & 1 stitch + adhesive & Survival until euthanasia day & Recent parietal thrombus \\
\hline
\end{tabular}

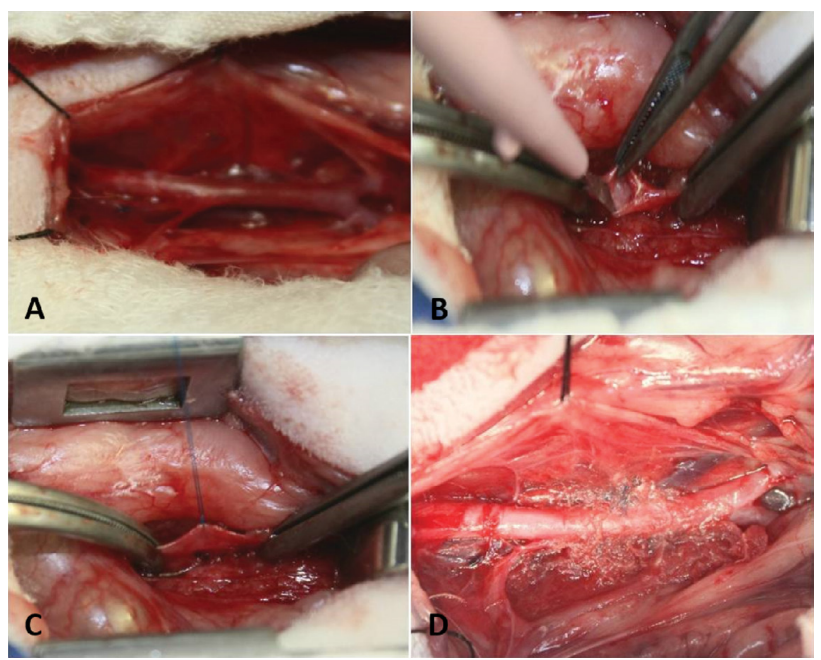

Figure 1. Sequence of procedures: A-Infrarenal aorta dissection; B--mm aortotomy (one forceps and the point of the electrocautery probe expose the vessel lumen); C- one suture equidistant from the arteriotomy edges; D-tissue adhesive was applied over the vessel, which was closed with just one suture.

\section{RESULTS}

All four animals in which the aortotomy was closed using four separate 7-0 polypropylene sutures without the adhesive suffered severe hemorrhages when the distal vascular clamp fitted to the aorta was opened. Despite intense compression with sponges, it was necessary to clamp the aorta again and to perform a repeat aortorrhaphy with running 7-0 polypropylene sutures in order to achieve hemostasis. All four animals had poor postoperative outcomes. Three of them died the day after the operation due to complications of the severe hemorrhage that occurred when the aorta clamp was opened (before the supplementary running sutures were performed). The fourth animal died about 60 hours after surgery due to intestinal ischemia, undoubtedly caused by excessive handling and long aortic cross-clamp time needed to stop the aorta bleeding (Table 1). The operations in which adhesive was applied progressed without hemorrhage or complications, but one of these animals also died within approximately 72 hours after surgery. This was probably due to sepsis, since it presented fever, tachycardia and tachypnea. Although the death of animal No. 5 was considered to be caused by sepsis, this case was nonetheless recorded as an unsuccessful outcome in the suture + adhesive group. No bleeding occurred in any of the animals in which the cyanoacrylate adhesive was used. As soon as the authors realized that cyanoacrylate adhesive was highly effective for sealing, they reduced the number of stitches used to suture the aorta in the group in which glue was applied after aortorrhaphy. As a result, the animals in the suture + adhesive group had aortorrhaphy 
conducted using four stitches (animal No. 5), three stitches (animal No. 6), two stitches (animal No. 7) or just one stitch in the center of the aortotomy (animals 8 through 12). Thus, although the last five animals submitted to arteriorrhaphy with the use of adhesive received only one stitch equidistant from the edges (resulting in an interval between the suture and the edges of approximately $5 \mathrm{~mm}$ ), no bleeding occurred.

The cyanoacrylate adhesive demonstrated efficacy in all eight animals in which it was used for sealing aortotomies. These aortotomies were of the same dimensions as those performed in animals in which a suture technique employing four separated stitches without adhesive resulted in hemorrhage of such intensity that it led to the animals' deaths.

Table 1 lists the procedures and results obtained.

For statistical analysis, the animals were divided into two groups as follows: a suture group, comprising four animals in which aortorrhaphy was performed using sutures only, and a suture + adhesive group, in which the animals received four, three, two or one sutures in combination with tissue adhesive.

The reason why the suture group was limited to just four animals was that all of these animals had poor outcomes due to severe hemorrhage and so that the authors were certain that it was unnecessary to continue to use this approach that would lead to the unnecessary deaths of more animals. The primary outcome (animal death) was compared across groups, including the animal in the suture + adhesive group that had probably died from sepsis.

Analysis of the endpoint (death) showed that technique including application of cyanoacrylate produced better outcomes $(p<0.010)$. Analysis of the time needed to perform aortorrhaphy using only suture (average time 39.7 minutes) and suture + adhesive (average time 4.31 minutes) also showed that using cyanoacrylate enabled quicker procedures $(\mathrm{p}<0.004)$, since aortorrhaphy using continuous sutures in a confined area was time consuming.

One month after the procedure, the surviving animals (seven) were euthanized with lethal doses of anesthetic and the segment of the aorta where the procedure had been conducted was examined. Segments of aorta extending from the infrarenal area to the bifurcation of the iliac arteries were withdrawn and submitted to anatomic pathology investigation, which revealed only parietal thrombus with an inflammatory infiltrate. During dissection of the aorta segment submitted to the procedure using suture + adhesive, no evidence of adhesions or major macroscopically observable local reactions was detected, but residues of cyanoacrylate adhesive were observed over the aorta.

The frequency of occurrence of intraluminal parietal thrombus in the animals in which adhesive was used could not be compared to the rate in animals in which aortorrhaphy was conducted using sutures only because none of the second group survived.

\section{DISCUSSION}

Bleeding along the suture line is a frequent problem that usually occurs in operations on blood vessels and which can prolong operating times and increase morbidity and mortality. Routine actions taken to avoid undesirable bleeding include gentle compression over the suture line, reversal of the effect of heparin injections and administration of oxidized cellulose. However, the introduction of tissue adhesives has provided a new approach for cases of mild to severe hemorrhage along the suture lines. ${ }^{4}$

There are two main types of tissue adhesives. Fibrin glue has been used for more than 30 years to promote hemostasis in several parts of the human body. ${ }^{3}$ This adhesive is effective in certain situations, but since it is prepared with a concentrate of plasma from several blood donors it involves the potential for transmission of viral disease. Additionally, it has been shown that fibrin glue provides insufficient adhesion force to support anastomosis without suture and is not recommended for vascular sutures.

When cyanoacrylate was first used as a surgical adhesive in 1940 it provoked a strong local reaction, but recent new formulations have exhibited low toxicity and limited local reactions. ${ }^{2}$ This was achieved by addition of an organic chemical group to the main chain of the chemical formula, increasing its absorption capacity. ${ }^{2}$ Cyanoacrylate glue has exhibited high effectiveness, quick fixation and strong enough tensile force to maintain tissues closed. ${ }^{1,6-8}$ Cyanoacrylate has also exhibited greater strength than fibrin glue for maintaining tissues together ${ }^{5}$ and for controlling bleeding from needle holes. ${ }^{2,4}$ This adhesive has the advantage of not being dependent on the patient's coagulation status and it can also be used in cases in which coagulopathies are present. ${ }^{9-11}$ There are different subtypes of this class of products and for the present study Omnex ${ }^{\circledR}$ (2-octyl-cyanoacrylate and butyl-lacoylcyanoacrylate) was chosen, which is formulated to biodegrade in a slow and safe manner over 36 months so that only small amounts of degradation products such formaldehyde are produced at any given time. ${ }^{12}$ Omnex ${ }^{\circledR}$ is the first Food and Drug Administration approved absorbable cyanoacrylate for internal use 
and is indicated for vascular sealing. ${ }^{12}$ It is available for immediate use in storage containers with integrated applicators, but should be applied in a 'dry field'.

The present study investigated the distance between two separate suture stitches that could be effectively sealed by the cyanoacrylate glue. The importance of this information is that if cyanoacrylate can provoke complete sealing even when larger distances are left between suture stitches, it should allow for quicker suture procedures and shorter duration tissue ischemia. In this study the cyanoacrylate adhesive proved to be an effective sealant for rabbit aortotomies in all cases, even when 10-mm aortotomies were closed with just a single suture stitch equidistant from the edges, with distances as long as $5 \mathrm{~mm}$ left free of sutures. Additionally, all of the animals in which only sutures were applied (without the use of adhesives or of other hemostatic substances) suffered major hemorrhaging from the spaces between sutures, showing that the adhesive is truly effective. Furthermore, the cyanoacrylate glue provided effective tensile strength, since these animals had systolic blood pressures of 90 to $130 \mathrm{mmHg}$ and diastolic pressures of 60 to $90 \mathrm{mmHg} .{ }^{13}$ This degree of effectiveness has prompted research to test the tissue adhesive in animal models of vascular anastomoses without using any sutures at all. ${ }^{1}$

The secondary objectives of this study were to observe macroscopically whether the cyanoacrylate adhesive produced a severe local reaction, important vessel wall changes, or severe adhesions to adjacent intestinal loops. In the present study we observed no remarkable degenerative changes to the aorta wall or adhesions to surrounding structures; but 1 month after the procedure there were still vestiges of the adhesive that had been applied to the vessel surface. An unexpected finding was observation of parietal nonocclusive thrombus in all aorta segments that had been subjected to the procedures. Since aortorrhaphy was performed by a trained surgeon using 7-0 polypropylene sutures and working with frontal lighting and a $2.5 \mathrm{x}$ magnification loupe, the reason for thrombus formation should not be attributed to technical flaws. Two other possibilities should be considered, i.e., the low heparin doses and the fact that part of the adhesive drains into the vessel between the sutures. One published study has shown that cyanoacrylate glue can reach the vascular intima sheath and be thrombogenic. ${ }^{14}$ In view of this, further studies are needed to determine whether this adhesive penetrates the lumen of the vessels. It is also possible, however, that the thrombus could be due to the low heparin doses used in this study $(100 \mathrm{mg} / \mathrm{kg})$. Heparin dosages vary between different studies, with Saba et al., ${ }^{1}$ for instance, using $100 \mathrm{mg} / \mathrm{kg}$ and Barbalinardo et al. ${ }^{8}$ using double this dose.

In conclusion, this study shows that cyanoacrylate glue promotes efficient sealing in rabbit aortas (mean blood pressure 70 to $90 \mathrm{mmHg}$ ) even when the distance between sutures is as long as $5 \mathrm{~mm}$, and requires a shorter time to achieve hemostasis. Gross tissue reactions were nonsignificant and there was no adhesion between the adhesive applied over the arteriotomy and the intestinal loops. However, nonocclusive parietal thrombus was found in all aorta segments treated with the adhesive.

\section{REFERENCES}

1. Saba D, Yilmaz M, Yavuz H, et al. Sutureless vascular anastomoses by $\mathrm{N}$-butyl-2 cyanoacrylate adhesive: an experimental animal study. Eur Surg Res. 2007;39(4):239-44. http://dx.doi.org/10.1159/000101893. PMid:17446710.

2. Ellman PI, Brett Reece T, Maxey TS, et al. Evaluation of an absorbable cyanoacrylate adhesive as a suture line sealant. J Surg Res. 2005;125(2):161-7. http://dx.doi.org/10.1016/j.jss.2004.12.014. PMid:15854669.

3. Brasil. Ministério da Ciência, Tecnologia e Inovação. Conselho Nacional de Controle de Experimentação Animal - CONCEA. [site on the internet]. Brasília: Ministério da Ciência, Tecnologia e Inovação; 2014. [cited 2014 may 05]. http://www.mct.gov.br/ index.php/content/view/310553.html.

4. Spotnitz WD, Burks S. State-of-the-art review: Hemostats, sealants, and adhesives II: Update as well as how and when to use the components of the surgical toolbox. Clin Appl Thromb Hemost. 2010;16(5):497-514. http://dx.doi.org/10.1177/1076029610363589. PMid:20699255

5. Jackson MR, Gillespie DL, Longenecker EG, et al. Hemostatic efficacy of fibrin sealant (human) on expanded poly-tetrafluoroethylene carotid patch angioplasty: a randomized clinical trial. J Vasc Surg. 1999;30(3):461-6. http://dx.doi.org/10.1016/S0741-5214(99)70073-X. PMid:10477639.

6. Ludsen AB, Heyman ER, Closure Medical Surgical Sealant Study Group. Prospective randomized study evaluating an absorbable cyanoacrylate for use in vascular reconstruction. J Vasc Surg. 2006;4:1002-9.

7. Shapiro AJ, Dinsmore RC, North JH Jr. Tensile strength of wound closure with cyanoacrylate glue. Am Surg. 2001;67(11):1113-5. PMid:11730233.

8. Barbalinardo RJ, Citrin P, Franco CD, Hobson RW 2nd. A comparison of isobutyl 2-cyanoacrylate glue, fibrin adhesive, and oxidized regenerated cellulose for control of needle hole bleeding from polytetrafluoroethylene vascular prostheses. J Vasc Surg. 1986;4(3):220-3. http://dx.doi.org/10.1016/0741-5214(86)90189-8. PMid:2427751.

9. Sileshi B, Achneck HE, Lawson JH. Management of surgical hemostasis: topical agents. Vascular. 2008;16(Suppl 1):S22-8. PMid:18544302.

10. Achneck HE, Sileshi B, Jamiolkowski RM, Albala DM, Shapiro ML, Lawson JH. A comprehensive review of topical hemostatic agents: efficacy and recommendations for use. Ann Surg. 2010;251(2):21728. PMid:20010084.

11. Kull S, Martinelli I, Briganti E, et al. Glubran2 surgical glue: in vitro evaluation of adhesive and mechanical properties. J Surg Res. 
2009;157(1):e15-21. http://dx.doi.org/10.1016/j.jss.2009.01.034. PMid:19439320.

12. Spotnitz WD, Burks S. Hemostats, sealants, and adhesives III: a new update as well as cost and regulatory considerations for components of the surgical toolbox. Transfusion. 2012;52(10):2243-55. http:// dx.doi.org/10.1111/j.1537-2995.2012.03707.x. PMid:22612730.

13. Marques RG, Caetano CER. Parâmetros fisiológicos em animais de pequeno e médio porte. In: Marques RG, editor. Técnica operatória e cirurgia experimental. Rio de Janeiro: Guanabara Koogan; 2005. p. 821-23.

14. Scheetz WL, Matsumoto T. Cyanoacrylate tissue adhesive: thrombogenic effect. Am Surg. 1970;36(7):418-22. PMid:4915721.
Correspondence Marcus Vinicius Henriques de Carvalho Faculdade de Medicina de Jundiaí - FM Rua Francisco Telles, 250

CEP 13202-550 - Jundiaí (SP), Brazi Tel: +55 (11) 4587-1095

E-mail: marcus.carvalho@sbccv.org.br

Author information

MVHC - MD, PhD. Cardiovascular surgeon; associate professor at Faculdade de Medicina de Jundiaí. EM - MD, PhD. Thoracic surgeon; associate professor at Faculdade de Medicina de Jundiai. MP - MD. General surgeon; assistant professor at Faculdade de Medicina de Jundiaí.

Author contributions Conception and design: MVHC Analysis and interpretation: MVHC, EM Data collection: $M V H C, E M, M P$ Writing the article: $M V H C$

Critical revision of the article: EM Final approval of the article*: MVHC, EM, MP Statistical analysis: MVHC, EM Overall responsibility: MVHC

*All authors have read and approved of the final version of the article submitted to I Vasc Bras. 